Illinois State University

ISU ReD: Research and eData

Theses and Dissertations

3-29-2019

\title{
Emotional Reverberations
}

Kirsten Heteji

Illinois State University, kirsten.heteji@gmail.com

Follow this and additional works at: https://ir.library.illinoisstate.edu/etd

Part of the Fine Arts Commons

\section{Recommended Citation}

Heteji, Kirsten, "Emotional Reverberations" (2019). Theses and Dissertations. 1112.

https://ir.library.illinoisstate.edu/etd/1112

This Thesis is brought to you for free and open access by ISU ReD: Research and eData. It has been accepted for inclusion in Theses and Dissertations by an authorized administrator of ISU ReD: Research and eData. For more information, please contact ISUReD@ilstu.edu. 


\section{EMOTIONAL REVERBERATIONS}

\section{KIRSTEN HETEJI}

\section{Pages}

Projecting psychological mindscapes onto domestic objects allows for an emotive and bodily connection to the domestic realm. Body, for me, is the clay and how it holds touch and softness indexically recording the actions of making in the final forms. Pushing, pulling and pinching clay evokes sensations that connect the maker's body as well as the observer of the work to participate. I shift expectations by experimenting between the hard and softness of bodily material like clay, giving it emotional fragility in how it contrasts the original structure it imitates. I think about creating objects and the arrangement them of them within a space as a way to create a metaphor of a person's psyche. My thesis show is about the physical experience of participating and relating to the objects as characters in the space. Instead of defining the psychological by enclosure, I want the viewer to enter into the space as participant. To blur the lines between physical and mental space the exhibition needed to appear more subtle and sparse than excessive. Projecting emotional affects to these domestic objects allows for an emotive and bodily connection to the space that surrounds you. The domestic objects resonate with emotion as if the reverberations of the mind have influenced the space around the viewer.

KEYWORDS: Ceramic, Clay, Body, Emotion, Domestic, Space, Object, Sculpture, Affect, Memory, Relationships 
EMOTIONAL REVERBERATIONS

KIRSTEN HETEJI

A Thesis Supportive Statement Submitted in Partial

Fulfillment of the Requirements

for the Degree of

MASTER OF FINE ARTS

School of Art

ILLINOIS STATE UNIVERSITY

2019 
(C) 2019 Kirsten Heteji 
EMOTIONAL REVERBERATIONS

KIRSTEN HETEJI

COMMITTEE MEMBERS:

Tyler Lotz, Chair

Albion Stafford

Nathania Rubin

Melissa Oresky 


\section{ACKNOWLEDGMENTS}

I would like to thank Mike Wille and Tyler Lotz for offering an opportunity to continue on at ISU as a graduate student. I am grateful for the patient and kind committee of Tyler, Albion, Nathania, and Melissa, and the faculty at ISU who all challenge me in different ways in which I'm grateful for. Thank you to my loving family Florence, Peter and Molly, and friends from home, Valerie and Ashley, who have been super supportive, even from a distance. My experience here has been unforgettable with the support of the community and friends throughout the years: Erin, Brian, Emily and Jake, Josh and Ryan, George and Jenny, Evelyn, Mariko, Jan, Jim, Bryant, Mary and Alanna. Thank you for all the hugs, laughs and lending your ears. I love you all.

K.H. 


\section{CONTENTS}

$\begin{array}{lr} & \text { Page } \\ \text { ACKNOWLEDGMENTS } & \text { i } \\ \text { CONTENTS } & \text { ii } \\ \text { FIGURES } & \text { iii }\end{array}$

CHAPTER I: INTRODUCTION AND THESIS SHOW ANALYSIS 1

$\begin{array}{ll}\text { Introduction } & 1\end{array}$

Analysis of Thesis Show $\quad 2$

$\begin{array}{lr}\text { CHAPTER II: CLAY AND BODY } & 8\end{array}$

$\begin{array}{ll}\text { CHAPTER III: COMFORT AND UNEASE } & 10\end{array}$

CHAPTER IV: REPRESENTATIONS OF SPACE AND MIND 13

$\begin{array}{ll}\text { CHAPTER V: CONCLUSION } & 16\end{array}$

$\begin{array}{ll}\text { WORKS CITED } & 19\end{array}$

$\begin{array}{ll}\text { APPENDIX A: ADDITIONAL IMAGES } & 20\end{array}$

APPENDIX B: LIST OF ARTWORKS 26 


\section{FIGURES}

Figure

1. Partial View of Fragmentations of a Hazy Mind Thesis Exhibition 2

2. Chair 3

3. Four Paned Window $\quad 4$

4. Lamp on Table $\quad 5$

5. Curtain (detail) 6

6. Fragmentations of a Hazy Mind Thesis Exhibition $\quad 7$

7. Detail of Chair 8

8. Detail of Bean Sprout in Bed 17 


\section{CHAPTER I: INTRODUCTION AND THESIS SHOW ANALYSIS}

\section{Introduction}

The clay becomes the conduit that connects body to place, drawing comparison between the texture of an object and the lines formed in my hand. They were once held, acting as a memory and traces of spaces or things that once were. Pressing your body into something, touching, feeling, knowing all you can about a thing before it gets lost in time. Obtaining a memory of something by collecting its sensations and recreating a positive from that cognitive distance. The figural nature of the clay, the body that contains remnants of my fingerprints, combines with this object. One cannot be seen without the other.

Like clay, people in relationships are impressionable, influenced by thoughts and actions, re-forming the self in relation to another. When relationships end, they leave traces in your life. An object made of clay can embody traces in this way. It can take on something else's form and be instilled with immaterial and visual qualities. Objects hold memories both indexically and intangibly.

An installation depicting a bedroom is the culmination of my work over the last three years. It consists of the re-creation of domestic objects in clay altered to indicate trace experience. Emotions reverberate into objects within the space around us, creating tangible connections that can reflect the corners of our minds. It evokes the anxieties that manifest from internal conflict between comfort and desire. The heightened state of mind causes contemplation of the psychological traces of relationships, veiling the self, and renewal from loss and doubt. The desire for happiness of the past or concern with worries of the future are embedded in the work. 


\section{Analysis of Thesis Show}

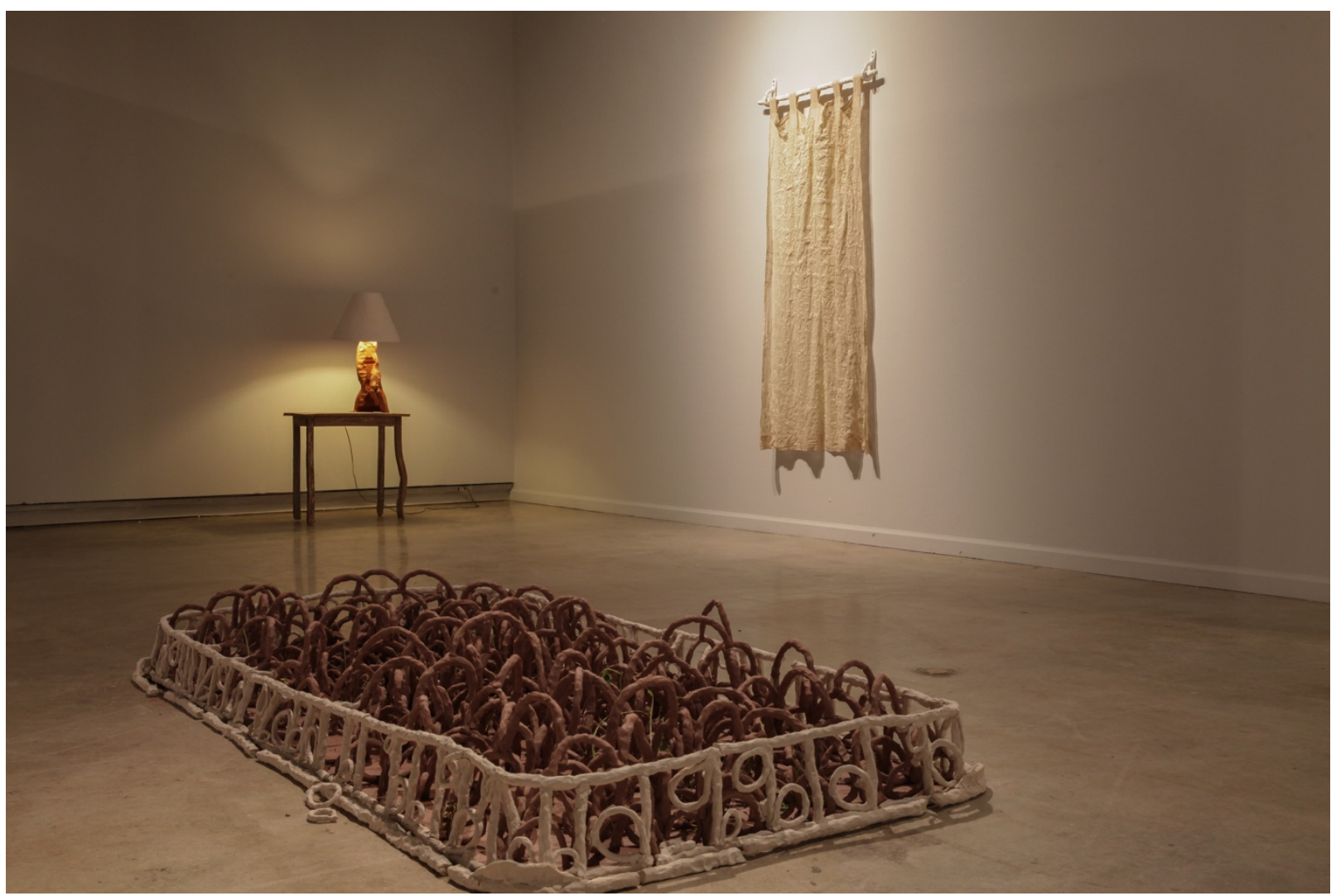

Figure 1. Partial View of Fragmentations of a Hazy Mind Thesis Exhibition

As the viewer walks into the space, they are confronted with a large structure on the floor. Undulating ceramic coils of unfired red clay are surrounded by an ornate unfired porcelain structure, resembling a boundary or gate. This bedlike structure, when covered for the first half of the show acts as a greenhouse, home for sprouts of seedlings wanting to escape from the dirt. When uncovered, partway through the duration of the show, the sprouts' destruction of the structure is revealed, as they grow through the drying, crumbly clay. The tallest seedlings sprout where a head would rest, showing how much the mind can feed ideas. As it dries for the second half of the show, the crumbling bed reveals further destruction and decay, as the seedlings lose their nourishment and moisture. 
The cycles of a garden bed intersect with cycles of life within the body and mind. The bed in the middle of the floor rather than a typical location against the wall reflects the vulnerability and exposure of thoughts and emotions, allowing it to read beyond a bed structure. The springy coiling mass of the bed structure feels like an open mind, but an unstable place to be.

Against the three walls surrounding the bed structure are other works that belong in a bedroom. A chair is facing a wall. A suggestion of a window sits across from the bed. A table supports a lamp in a corner. A singular curtain hangs on the wall adjacent to the bed. The use of clay is consistent throughout. In an open gallery, the recreation of a lived space allows for each work to occupy its own space but still enter into conversation with the other works, similar to the sorting of thoughts in one’s own mind.

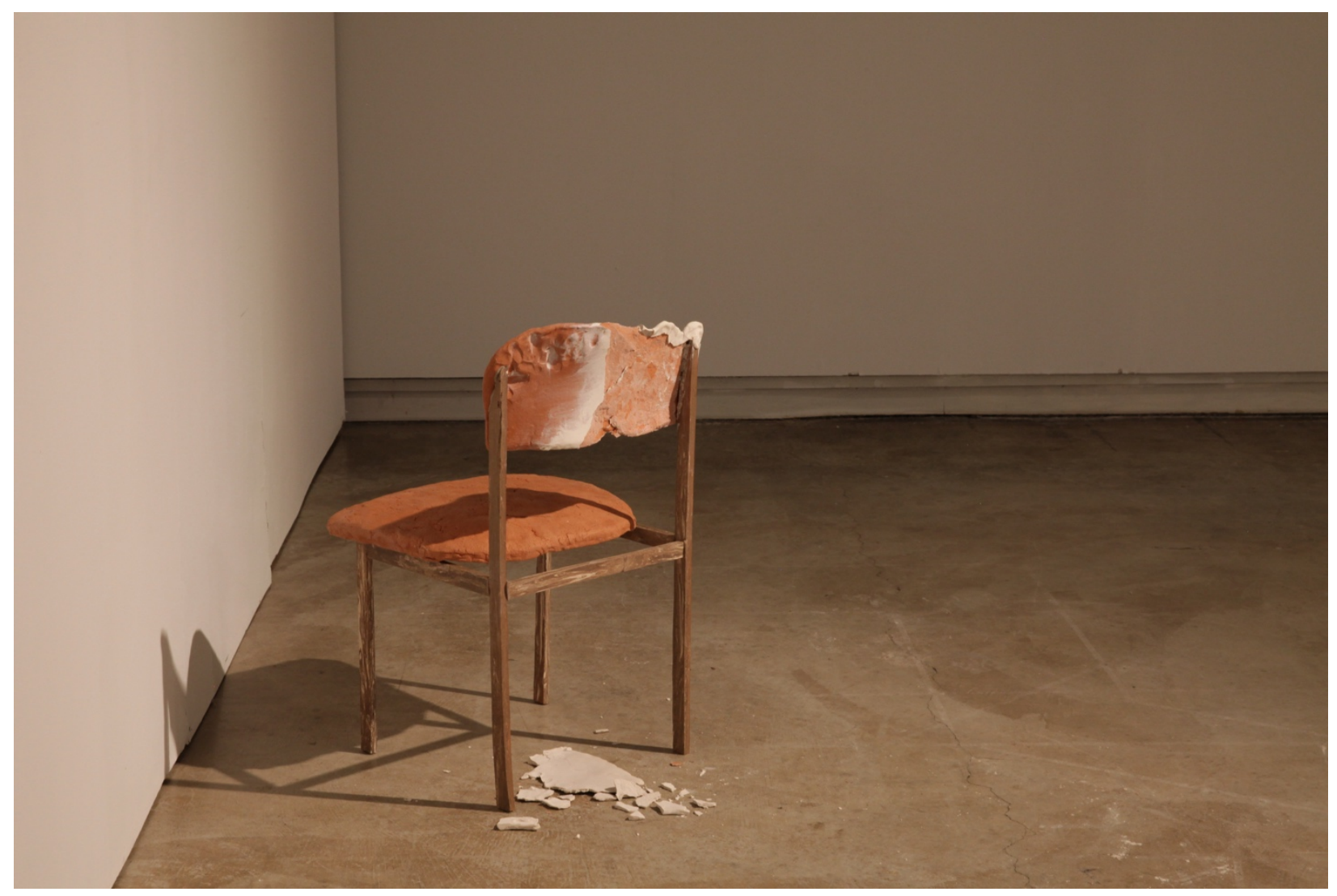

Figure 2. Chair 
The chair's thin legs appear wooden, bracing a slightly supportive back and seat. It's worn and cracked red clay seat shows signs of age and wear. Impressions of fingers in the clay appear on the seatback that would have once added comfort to the person who would rest on this chair. It has a similar emotion and touch as the structures within the bed.

Additionally, part of the red clay seatback and shoulder has been repaired with unfired porcelain that has broken off. It reflects the loss of part of itself while it sits in silence. It feels as if the psychological effects of loneliness have affected its structure. The chair faces the wall, as if it is in time out, unable to engage with the other works. It is left with traces of time and past interactions.

Arranged in a two by two square in the manner of a four paned window, paper thin ceramic panels are backlit and apparently float from the wall. They glow with a brightness that cannot shine through the clay sheets, but escapes from the sides, giving a halo to each panel. The familiar window has been reversed, the negative becomes the positive. What would be clear and transparent is blocked. The light escaping from the edges leaves a yearning to know what might be on the other side of the window. The bright lights become more prominent in the dark, shining with hope: a bright silver lining to the darkness.

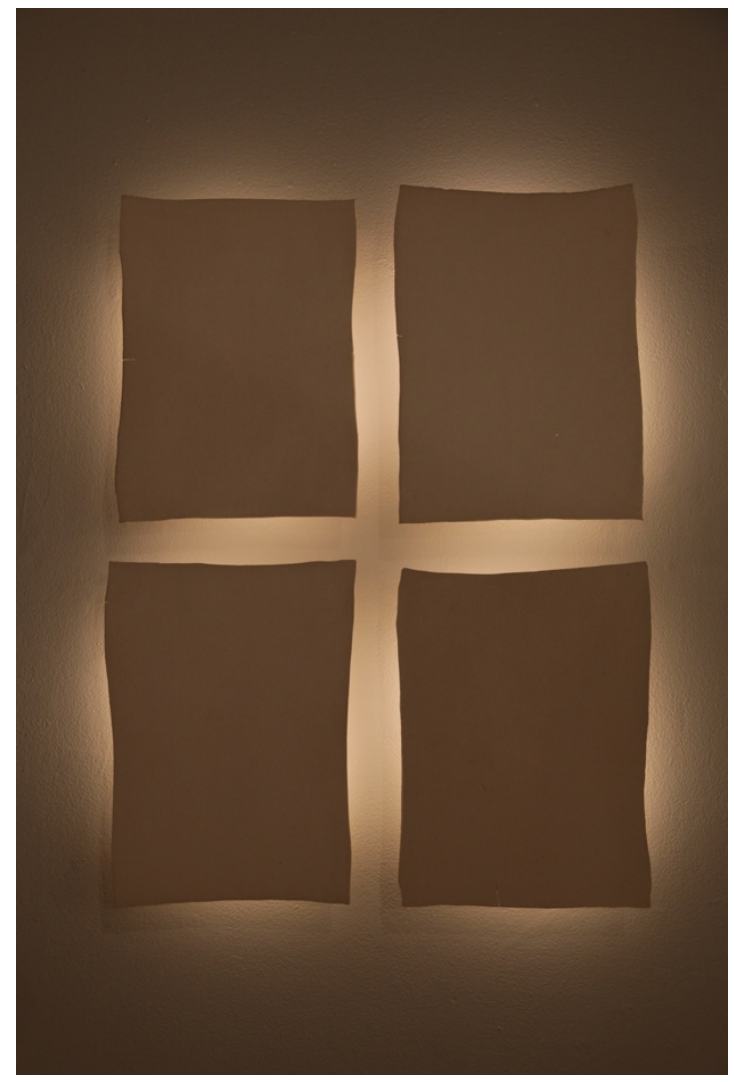

Figure 3. Four Paned Window 
Standing sturdy and tall, a trace imprint of a lamp sits on a table in the corner of a room, its structure is evidential of the clay having enveloped the base of a preexisting lamp. The clay impression undulates and moves as its own object. The lampshade appears normal at first glance. With a closer look, the shade reveals the subtle pinch marks creating an uneven surface. Light can only escape from the top and bottom because of its opacity. The glow projects eerie beams of light similar to the window structure on the wall nearby.

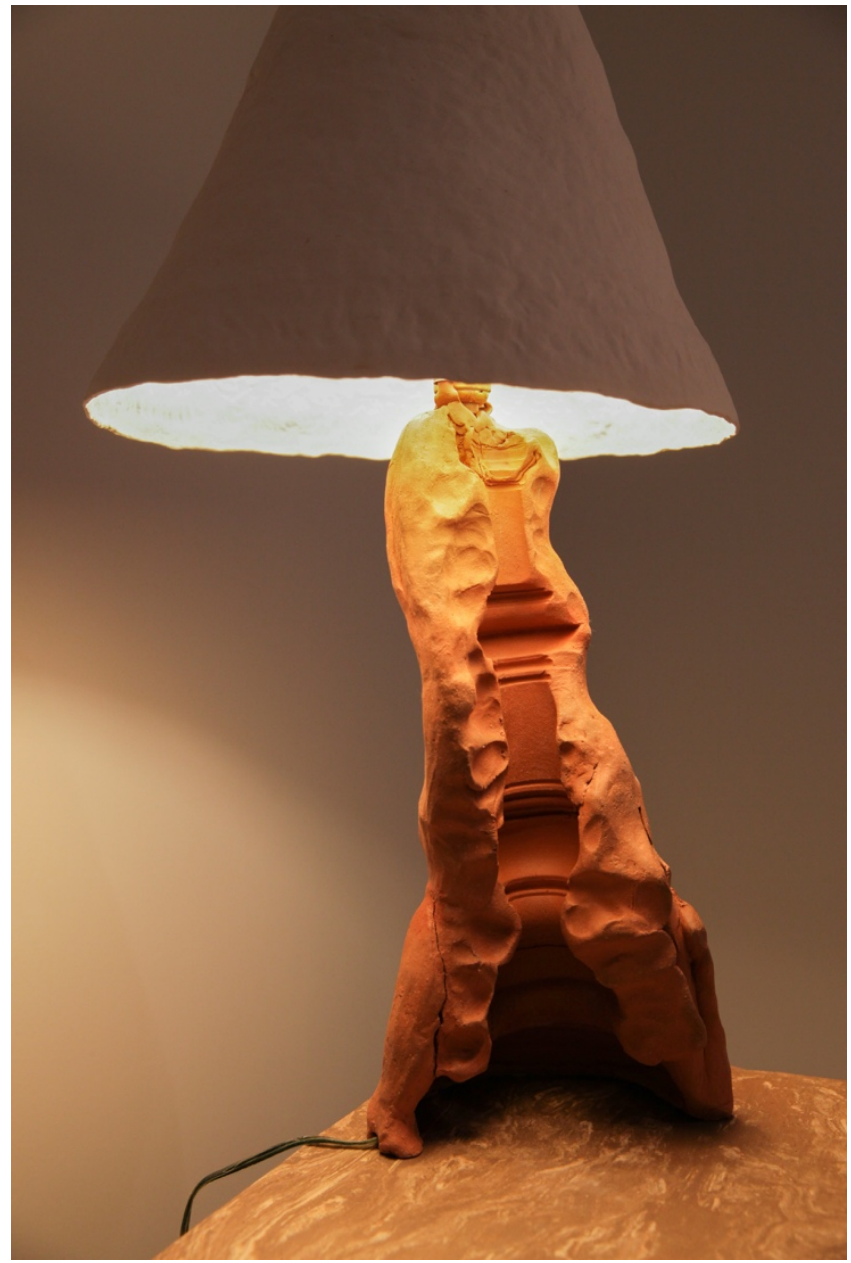

Figure 4. Lamp on Table
The table appears as wood, but the illusion is disrupted by its imperfect edges. The legs show signs of wear and the unsquared feet don't touch the ground with a perfect step. Standing on the nubs of its tippy toes, the table has a curved leg that breaks out of the usual straight, squared support. The movement in the leg relates to the curvature of the lamp’s impressed clay form. The lamp and table both reveal a more playful aspect in their bodily movements.

A curtain hangs on the wall adjacent to the bed appearing to be a beautiful embroidered window cover. It is held up by pinched clay porcelain hooks gently grabbing the curtain rod. The hooks imply the lose grip of a finger curling in to meet the thumb. Emulating the creation of the bed's structure, traces of my hand gripping the clay appear in the rod and hooks. 
The white clay hardware blends in with the wall, giving the tan curtain prominence. The curtain drapes with strain from the weight of the liquid clay words permeating the fabric. The undulating lines created by the illegible script have a similar form to the arch structures of the bed. The crumbling dried words face the wall so only their backs are seen through the curtain. Comparable to the light of the ceramic window panes and the lampshade, the curtain functions by veiling something which is usually seen. The written passage on the curtain speaks to a veiling of the self. The illegibility of the passage

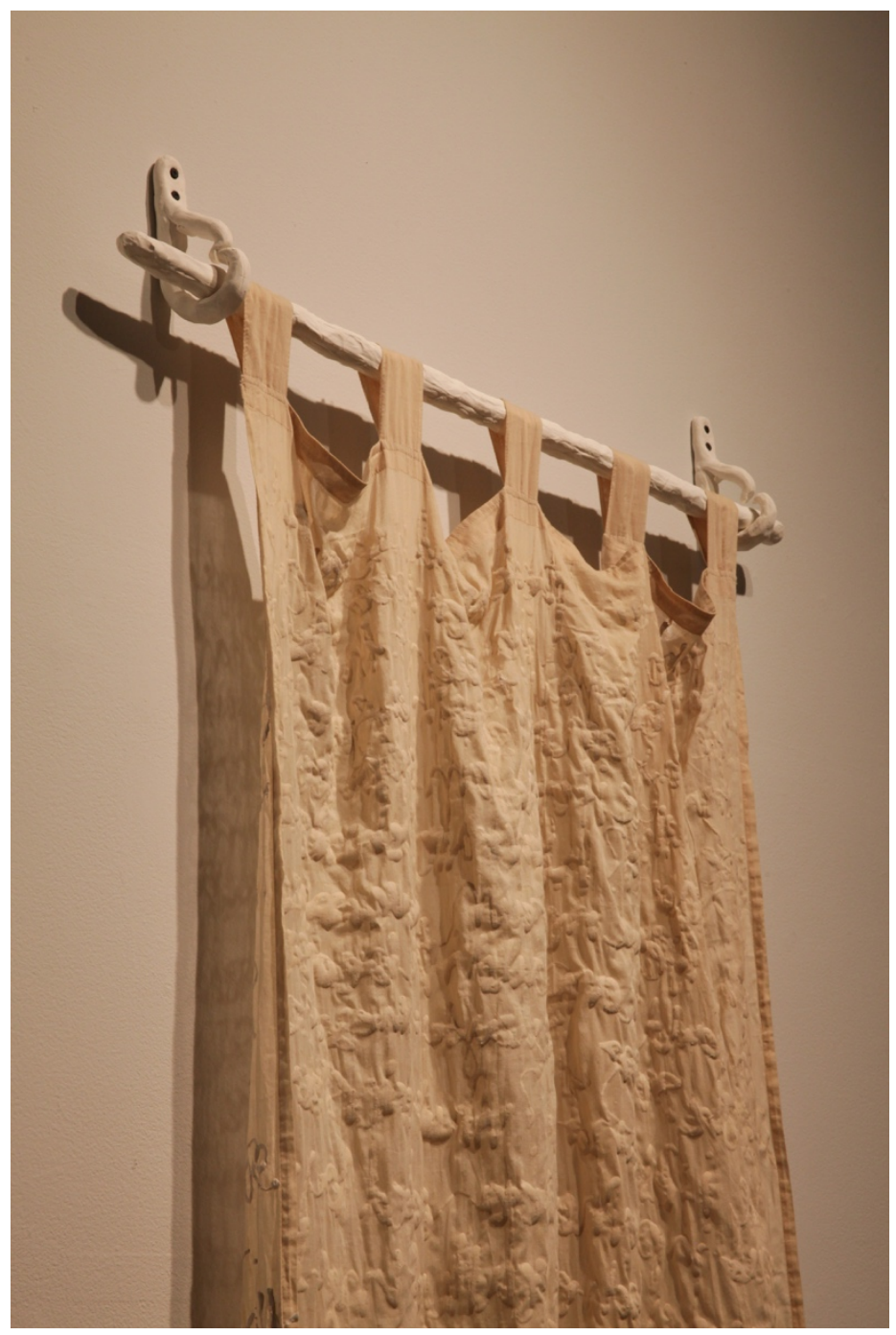

Figure 5. Curtain (detail) implies the blindness caused by hidden desires becoming apparent upon personal reflection of past events. Fragile unfired clay words clinging to the curtain feels similar to unanswered thoughts that linger in the back of the mind. The speed and tenderness of the script resembles thoughts that come and go.

Presented in many forms of clay, Fragmentations of a Hazy Mind reflects upon feelings of veiling the self, psychological traces from relationships, and renewal within loss and doubt. The raw unfired clay throughout the work in the exhibition evokes thoughts of purity with an ethereal 
white porcelain, earth and body with the red clay and the range of fragility and solemnness between them. The contrast between pale object and shadow speaks to the ephemeral and untouchable parts of the mind; the immaterial nature of seemingly tangible things.

All of the work is intertwined by a sense of touch in the ceramic medium varying from the press of a finger to the imperfectly curved edge of a paper-thin porcelain slab. The different approaches to working in clay reflect the ever-changing emotional self. The material summons the sense of the body and imperfection implying a muddling of the mind and the influence of melancholic emotion.

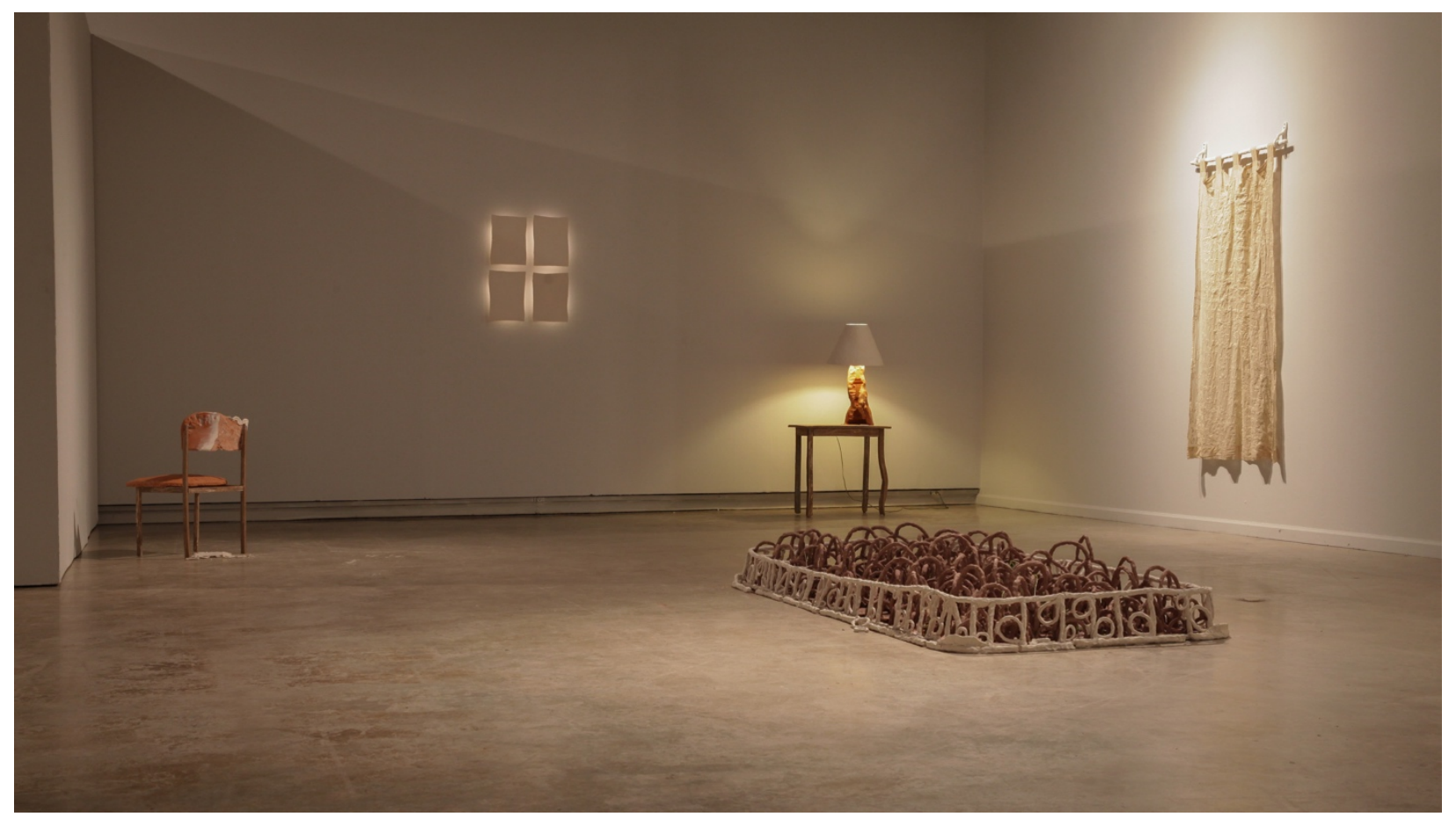

Figure 6. Fragmentations of a Hazy Mind Thesis Exhibition 


\section{CHAPTER II: CLAY AND BODY}

The objects in my installation are all made of clay. In this work, clay can act as the conduit between body and emotion. The material becomes a metaphor for the reinterpretations of memories or moments within the everyday. The bed more explicitly reveals the visceral nature of the clay. How the clay is squeezed and manipulated through my fingers is a visual reverberation of anxieties within these objects. The unfired clay reflects the fleeting nature of time and the declining strength of memories. Time can be wasted looking to the past or being anxious about the future. Memories can be released by choice, letting go in hopes of something better, or they can

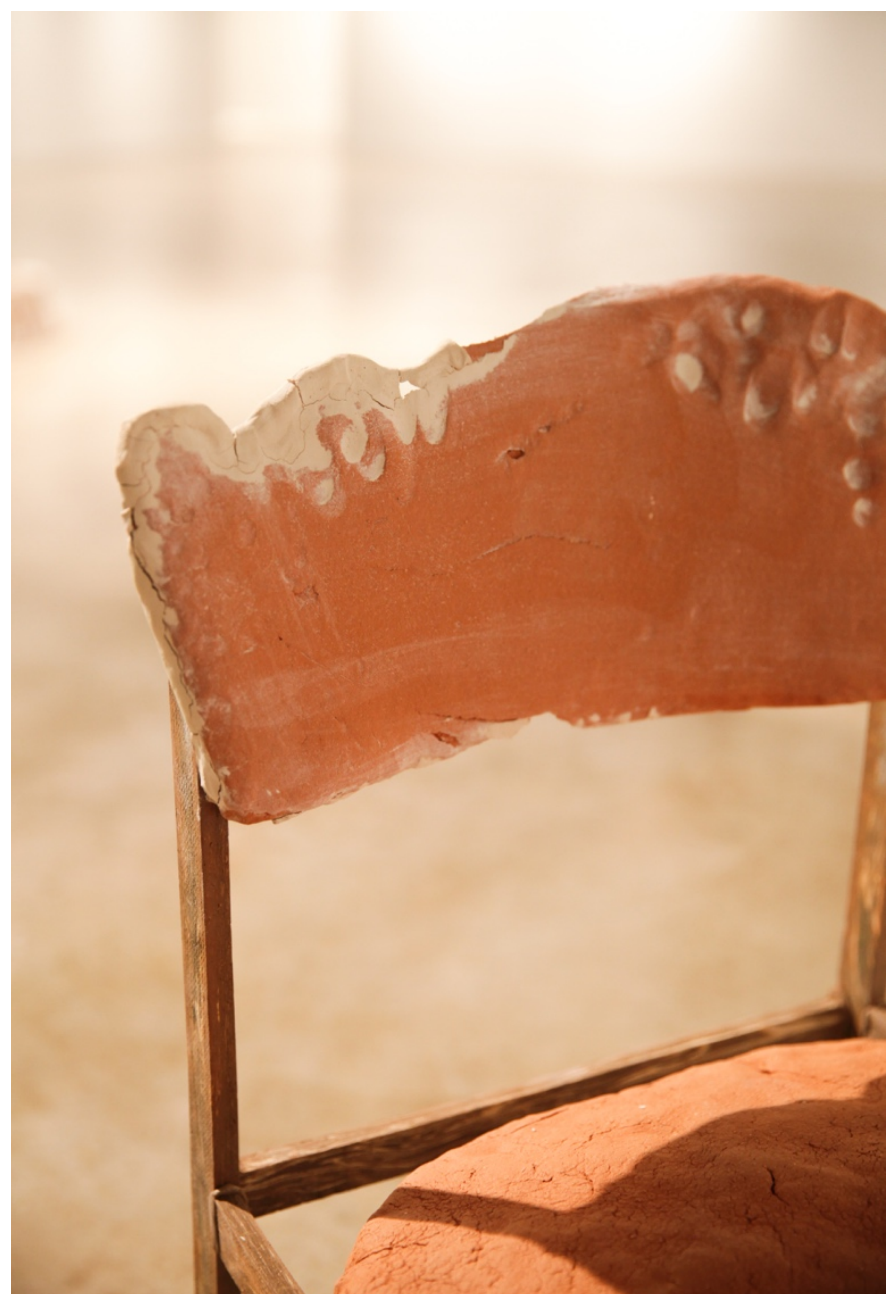

Figure 7. Detail of Chair diminish in the brain over time.

I currently experiment with the poetic rawness of clay. Through creating gestures and subtle shifts in the recognition of objects, I cause them to relate to a cerebral space between reality and fiction. Clay is a muddled translator, obscuring and contrasting the function of the original objects they imitate. Clay as a material becomes a metaphor for human existence; a vessel of meaning. Forms become relatable as they personify personalities or emotion. The sculptures become a 
connection to human existence drawing empathy without using direct figuration.

The tactility of clay provides an intimacy and desire for physical and emotional connection. Projecting the psychological onto domestic objects allows for an emotive and bodily connection to the spaces they inhabit. Clay, as a material, holds touch and softness, indexically recording the actions of making in the final form. The recording nature of clay evokes sensations that connect the viewer to the maker's touch.

In the objects I've made, I also shift perceptions by experimenting between the hardness and softness, sturdiness and fragility of materials. These tactics in making give a sense of an object's emotional dimensions as it contrasts with the original structure it imitates. A table made of clay appears more fragile and vulnerable in its bodily appearance. The softness of clay allows for tactile imperfections that undermine its function of being stable. The hard and soft attributes of clay reference the same way we describe people and how they carry their emotions. Clay is a material that is humble and unsure of itself; an awkward strength. The material's duality embodies these moments of projected anxieties and vulnerabilities as well as its confidence and strength as a physical object. The sculptures take on this role as interpreter of these displacements I feel from everyday interactions. 


\section{CHAPTER III: COMFORT AND UNEASE}

The light seems dim. People around me know how to see it, how to find it, they have learned to embrace it. I can see its glow, but I don't know how to reach it. It feels like things always get in the way. Maybe something is in the way, clouding my vison. Am I blind to the sensations that give way to luminesce? This barrier is something I created, clouded by expectation and self-doubt. How have I felt it but not seen? The answer glows with brightness, but still I struggle to find my own way.

My work is focused on poetic representations of these challenges of comfort and desire, creating objects and spaces reflecting frustrations within myself. Making the work helps me explore those feelings in a therapeutic way; helping me learn to let go and accept the uncontrollable.

I question my own thoughts and feelings about the relationships I have with other people, places and things. There is back and forth between caring for the self, caring for others and clarifying the needs of both. The internal conflict that arises from this discrepancy manifest as explorations of unease in my work. Although satirical and poetic, the work becomes reflective of comedic and questionable interactions with others. I like to find the humorous aspects of social constructs, determining how to act, think and feel in terms of relationships with ourselves and others.

A rigid plastic light switch translated into a large-scale soft sculpture created by Claes Oldenburg changes our knowledge of the object. The viewer feels sympathy for the emotional sagging structure hanging from the wall, seeming limp and sad. The play between soft and hard, 
the organic and architectural, creates a space to comment on comforts and desires. The fluidity of the soft sculptures adds a pathetic quality to them. Their new functionless nature projects the humor in sadness. By reinterpreting everyday objects into materials that subvert their original function, Claes Oldenburg challenges our perception of objects. He rescales the objects to be the size of our bodies, providing monumental changes our understanding of the importance of objects. Oldenburg believes the "object is a device of a transfer of the inside to the outside- a container, the starting point." ${ }^{1}$ The qualities of these objects translate the feelings within us to the physical forms being recreated.

Other people can subtly shift and change me in ways I don’t realize until they drift away. The external influences on my identity and emotions from relationships isn’t always immediately identifiable. Such influences cause me to pay more attention to why I feel the way I feel, during moments of distress and discomfort. The state of mind of my thesis show is formed by the influence of emotion manifested in the restructuring of the objects themselves. This projection of feeling into form creates an affective experience.

Affect, as a concept, relates to an instinctual reaction of a feeling before it becomes definable. Through the experience of my work as the viewer recognizes the nuances of clay and object, it presents feelings of affect. Thinking through the changes in the recreated domestic object starts to impact the viewers empathy for the object. The emotional and affective influences projected onto the objects within the installation space of my thesis show is more solemn and subtle for this reason. The viewer is put in a position to be attentive and look for subtleties that

\footnotetext{
${ }^{1}$ Arthaus Musik. Claes Oldenburg. 2019, https://illstu.kanopy.com/video/claes-oldenburg. Accessed 24 Feb 2019.
} 
reflect these kinds of feelings and experiences. The discovery of nuances within experience address the psychological makeup of an individual's identity. 


\section{CHAPTER IV: REPRESENTATIONS OF SPACE AND MIND}

Interior spaces reflect those who occupy them. Walking into an older home, one sees the signs of wear, a lived-in space. In these spaces, perhaps there are modest wooden floors, imperfections around a window's edge, or a creaky door which doesn't close all the way. Spaces begin to take on personalities in their functions and their makeup. The objects one collects and cherishes, both the clean and disheveled piles in the periphery, reflect the occupant's personality and state of mind. Our domestic objects can show signs of favoritism. The arms of a chair show wear from countless times of being touched, the transferred dirt rubbed into the fabric. From the years of interaction, the seat conforms to a particular body. Spaces of comfort share intimate moments with the occupant's identity.

Inhabitants surround themselves with what they are attracted to. Some look for the vintage and the nostalgic by shopping at thrift stores and looking for antiques. Family heirlooms retain history and timelessness, representing a sense of the familial throughout generations. People are attracted to certain qualities of things such as integrity, reliability, and humility. They reflect our own values and those of the person who owned them before. In The Architecture of Happiness Alain De Botton states, "What we search for in a work of architecture is not in the end so far from what we search for in a friend. The objects we describe as beautiful are versions of the people we love.” ${ }^{2}$ These objects people surround themselves with hold a special place in our hearts, because they define our identities, our thoughts, feelings and memories. These become the collective self.

\footnotetext{
${ }^{2}$ De Botton, Alain. The Architecture Of Happiness. Pantheon Books, 2006, p. 18.
} 
I create objects and arrange them within a space as a metaphor for a person's psyche. My practice becomes a platform to talk about comfort and stability, and the emotions that can conflict with these ideas. Similarly, Louise Bourgeois' Cell series are installation spaces embodying psychological happenings trapped in the mind. They juxtapose real and made objects in different ways creating anxiety of domestic spaces. They can be seen as psychological confines for remembrances of past events in relation to trauma over time. Like The Cells, my installation also operates by providing a microcosm of the mind projected through objects within a structured space. Bourgeois' Cells are bound by a series of room dividers made up of old found doors, hinged together, forming an enclosing circle. Some of these doors only allow a window to peer inside while others have a gap to look through. The closed off space invites the viewer to participate in voyeuristic activities of looking but not touching, distancing the interaction with the arrangements of objects inside. Within Cell I, an arrangement of beakers, flasks, stainless steel medical instruments and kitchen utensils on a nightstand conflicts with what we know should exist in a bedroom. The peculiar arrangement of found and sculpted objects within the space suggests a singular person struggling to understand oneself through the eyes of the past.

My thesis show is about the physical experience of participating and relating to the objects as characters in the space. Bourgeois defines her spaces by enclosing an installation of found and made objects. The excessive blending of the real object and the psychological projections pulls in the viewer to discover and explore this space within the mind. It brings the viewer to a place of obsessiveness and anxiety physically boxed in a space that contains the darker parts of the subconscious. I define my installation by open space, implying boundaries by the wall's aligned edges with the floor. Granting accessibility to the space allows for a flow of experience, similar to revisiting a thought in the back of your mind. I envision the storage spaces of memory and feeling 
defined as corners of the subconscious rather than enclosed. Memories can be recalled from a single fragment of a multi-sensory experience. To blur the lines between physical and mental space the exhibition needed to appear subtle and sparse to reflect the limitations of remembering. Feelings challenging comfort and desire arise from the involvement within the work. Having the viewer connect the subtleties between the objects is part of the experience of piecing together the mental state of the inhabitant of the space. These objects are the outcome of the occupants interpersonal perceptions of past events. 


\section{CHAPTER V: CONCLUSION}

Familiar objects behave as figural representations of emotional reverberations from my subconscious. These domestic objects, through alterations in their making, offer emotional resonance emblematic of a life lived. Although each work can stand on its own, the personalities of the individual objects have broadened to collectively form thoughts about how that life was lived, and what was felt throughout it.

I observed how by proximity the objects in the installation began to communicate through their similar shapes and ideas that resonate in them. Themes of veiling occurred with the window and lamp light as well as the illegible words on the curtain. The visible sense of touch can be traced in the bed, the curtain rod and the deep marks on the back of the chair. This collection of sculptures informed each other regardless of the various interventions on the material in each object.

The re-evaluation of each artwork causes a questioning of reality similar to an obsessively overthinking mind. The chaotic structure of the bed perhaps references synapses over-firing in the brain, thus causing the rest of the objects in the space to distort in response of this magnified distress. Variations of formed clay purposefully added to the muddling of perception in the space.

I intend for viewers of the installation to walk away feeling empathy for the objects in the space. The evaluation of these works open possibilities of influence on how viewers might look at other objects they come across in their daily lives. Examining their own chairs at home to see the nuances where it is touched and how it shifts position when you interact with it would promote new insights and appreciation. Imagining the feeling of the undulating stiff coils of the clay bed questions comfort before laying down on their own at home. Interacting with my work can also 
influence the perception of seeing objects as more like ourselves, leading some to treat their space perhaps like their own family.

I think it was important for me to examine more sparse and raw emotions through the materiality of clay in its different states of formation. Having worked with fired clay for so long, using raw clay opened up a lot of opportunities for expressing new content about memory and emotion. Raw clay offers a time-based quality to the experience of a work. The visual representation of elapsed time in raw material can be interpreted as the deteriorating innerworkings of the mind. As a representation of the subconscious, the bed reflects cycles of thoughts and memories through the unfired structure. Formations of preexisting ideas break down to make way for the seedlings of thought to flourish. The chair's unfired repair drying and falling off is comparable to fragility and defeat when feeling alone. Degradation and the passage of time in the experience of the work is out of my control. My own limitations are comparable to troubles we all encounter with recollection and remembrance throughout our lives.

My work initiates conversation about

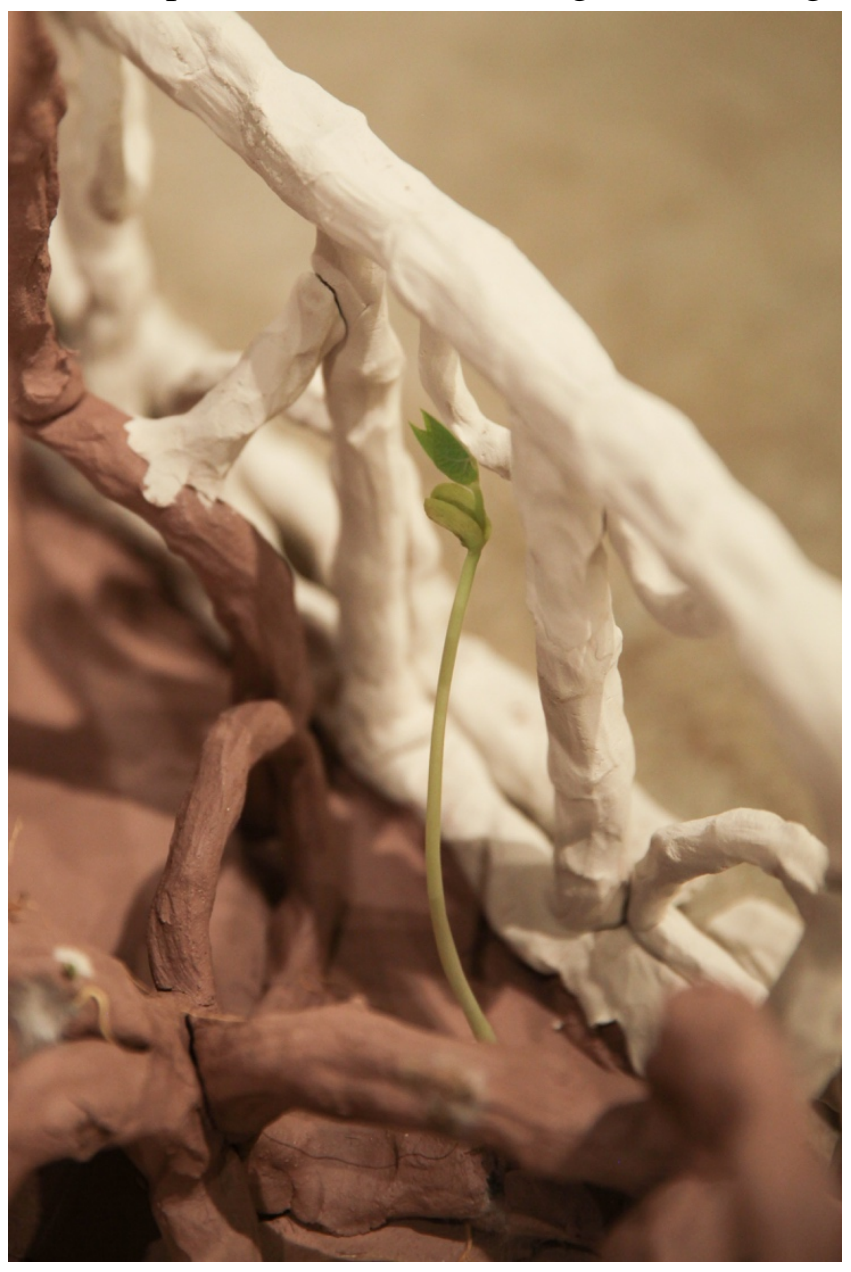

Figure 8. Detail of Bean Sprout in Bed being more open and aware of affects and emotions; in ourselves and others. In a world where we are frequently looking into our phones, a greater polarity is formed between communication and 
interaction. The separation of the physical from the social has degraded the quality of our connections with each other, infringing upon our capability for empathy. Seeing pictures or words is not the same as experience and conversation. Artwork that creates this empathetic involvement enriches the community by causing discussion about these deeper experiences with one other. My installation is a counter point to this digital space by physically connecting memory to objects. It presents a reality that relates to experience differently, slowing down access to the ideas in the work. An otherworldly sense of time is present in the leisurely pace spent between each object and the various stages of drying and fired clay. The haptic qualities of the objects affect people on a deeper level, creating a more visceral connection of body and place. These alternative methods of relaying information allow for longer lasting moments to form emotional and empathetic connection, leaving viewers with a new understanding of time and memory, and maybe themselves. 


\section{WORKS CITED}

De Botton, Alain. The Architecture Of Happiness. Pantheon Books, 2006.

Arthaus Musik. Claes Oldenburg. 2019, https://illstu.kanopy.com/video/claes-oldenburg. Accessed 24 Feb 2019.

Shouse, Eric. "Feeling, Emotion, Affect". M/C Journal, 2019, http://journal.mediaculture.org.au/0512/03-shouse.php.

Storr, Robert et al. Louise Bourgeois. Phaidon, 2010. 
APPENDIX A: ADDITIONAL IMAGES

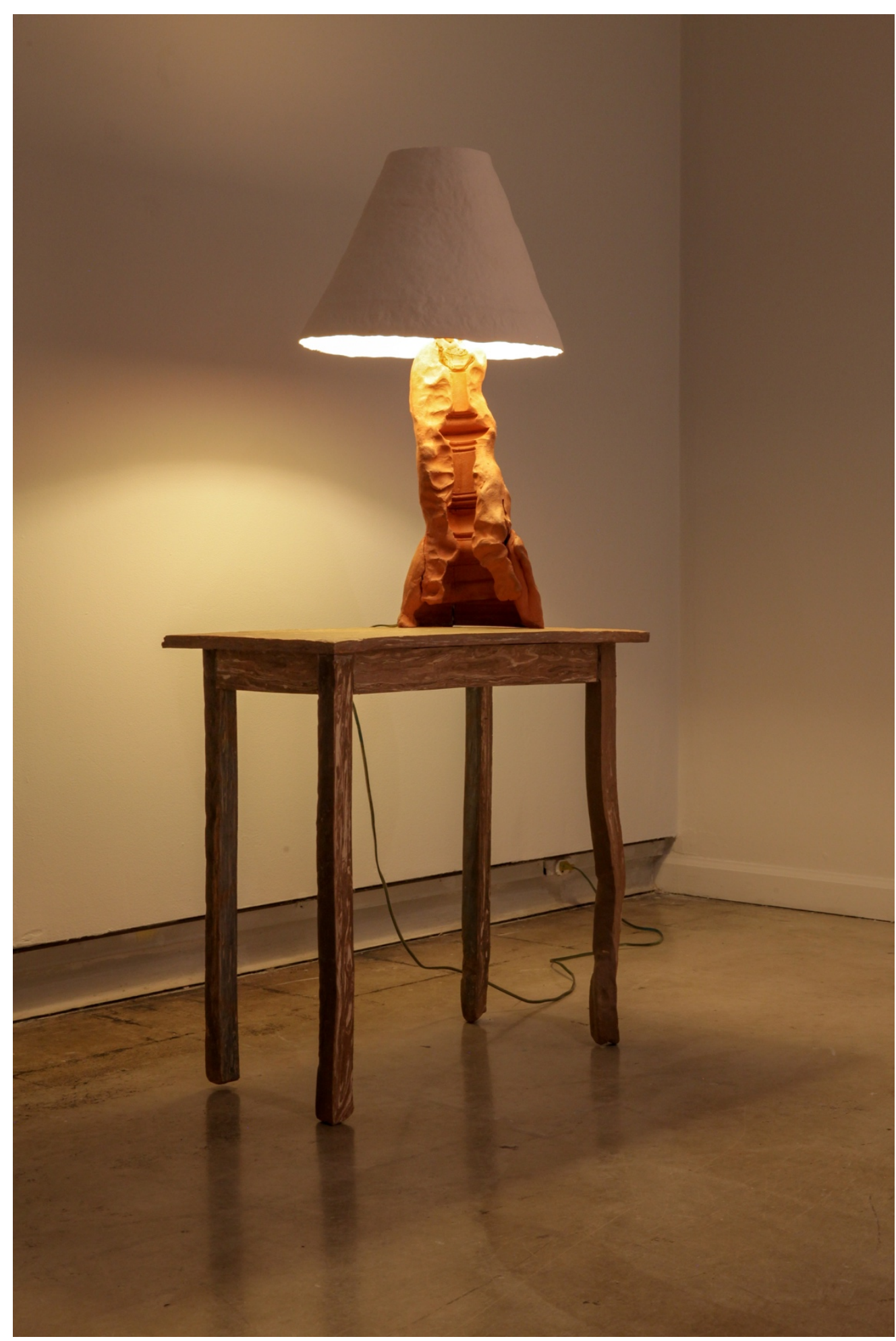

A-1. Lamp on Table 


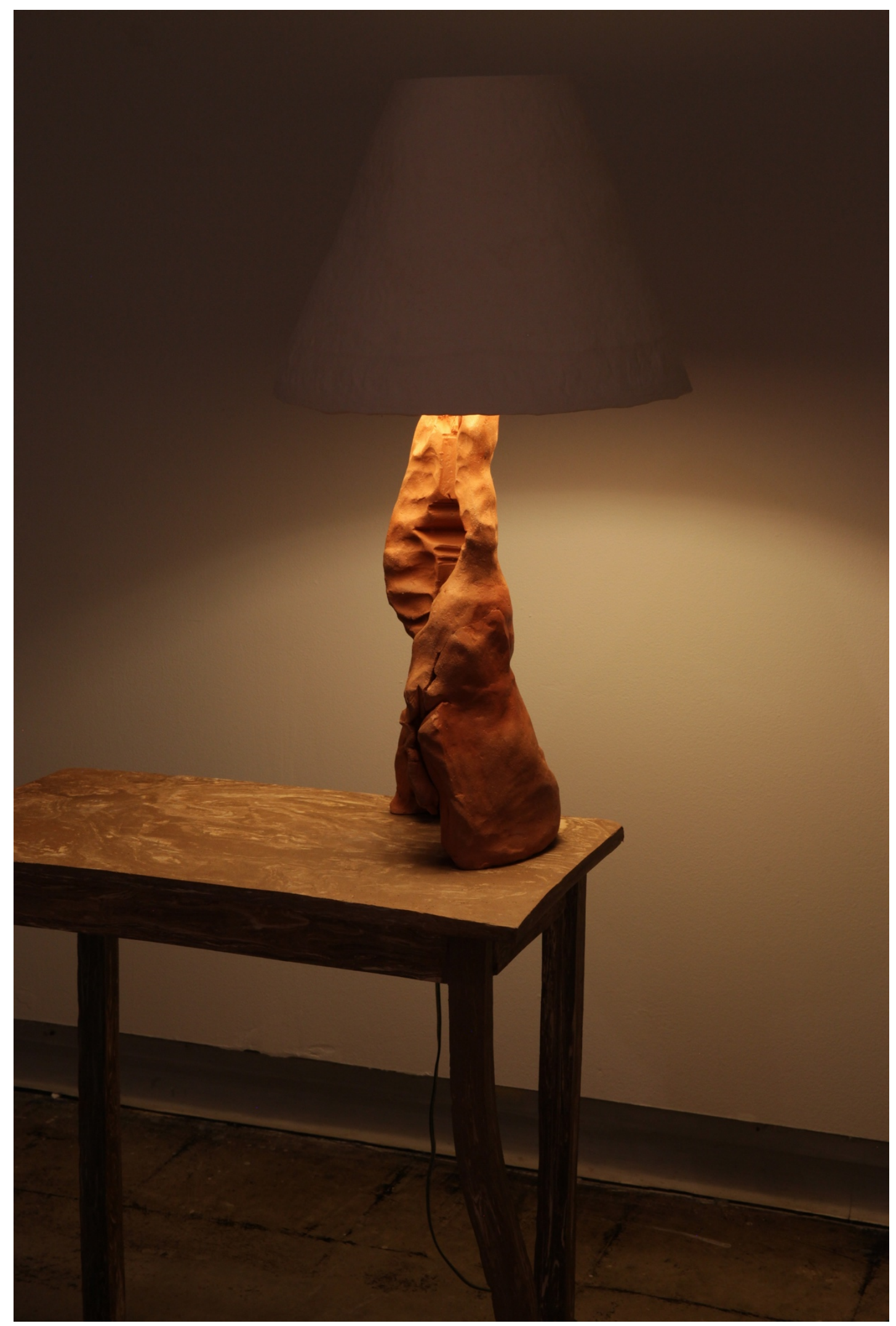

A-2. Lamp on Table (Alternate View) 


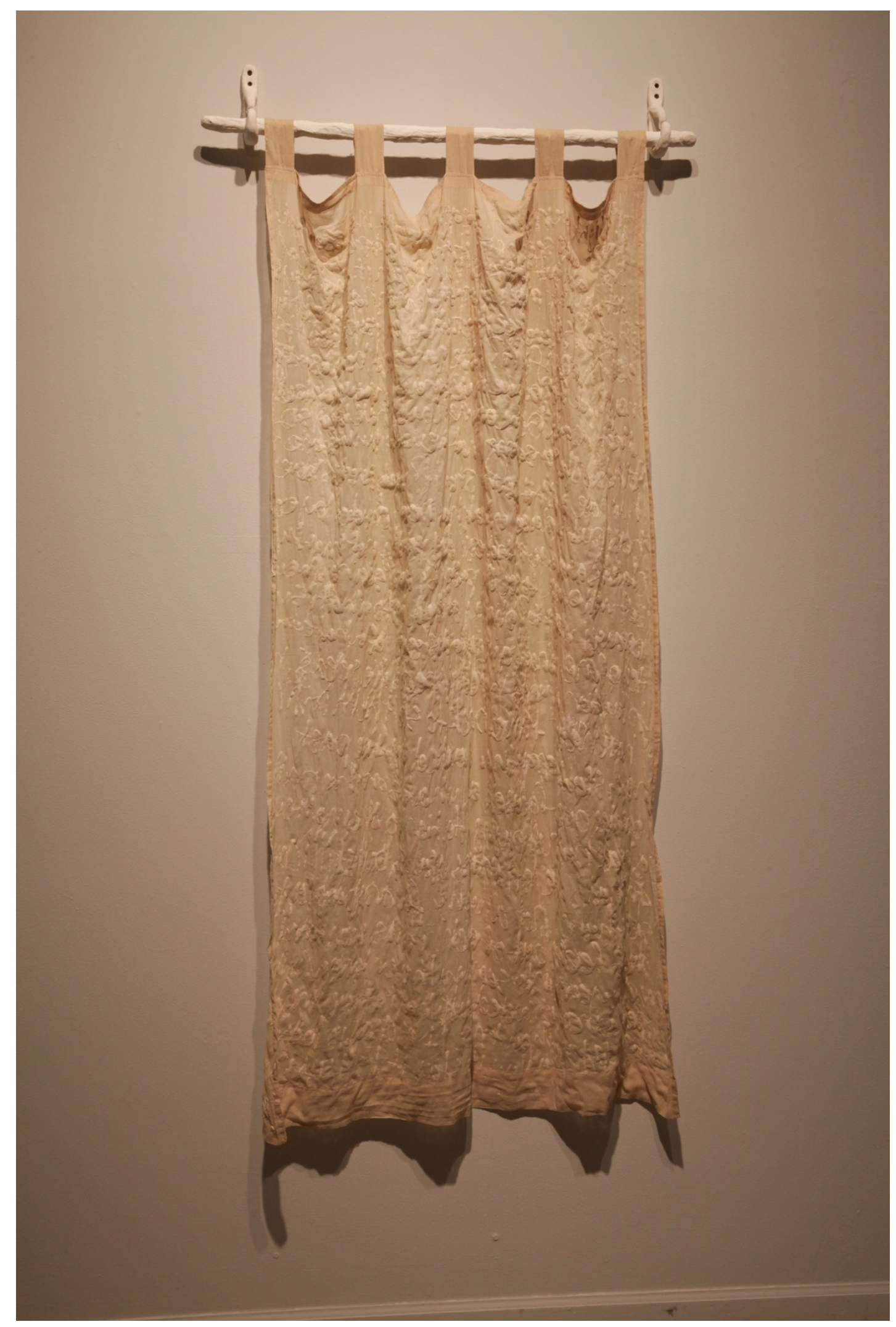

A-3. Curtain (Full View) 


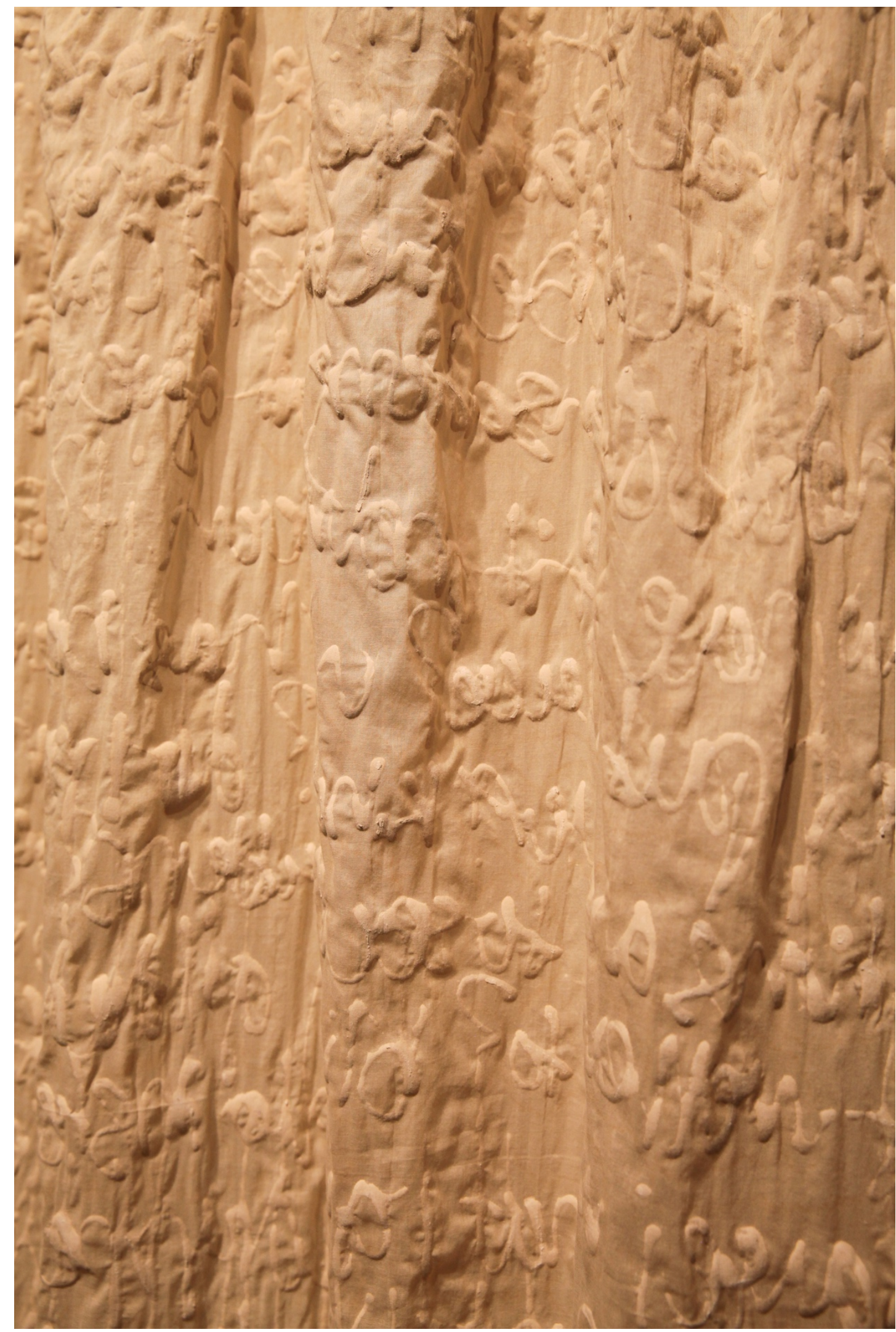

A-4. Curtain (Detail) 


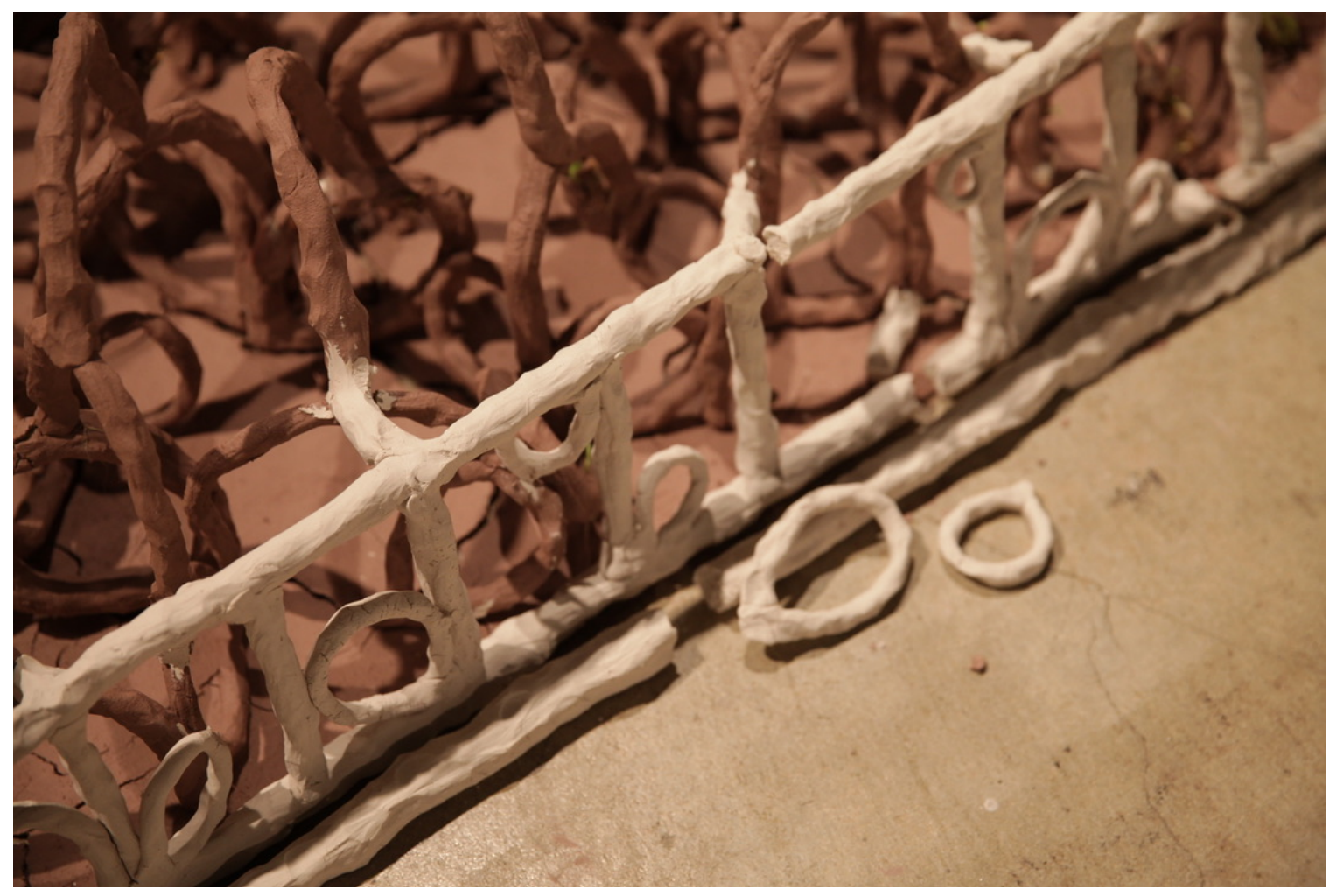

A-5. Bed (detail)

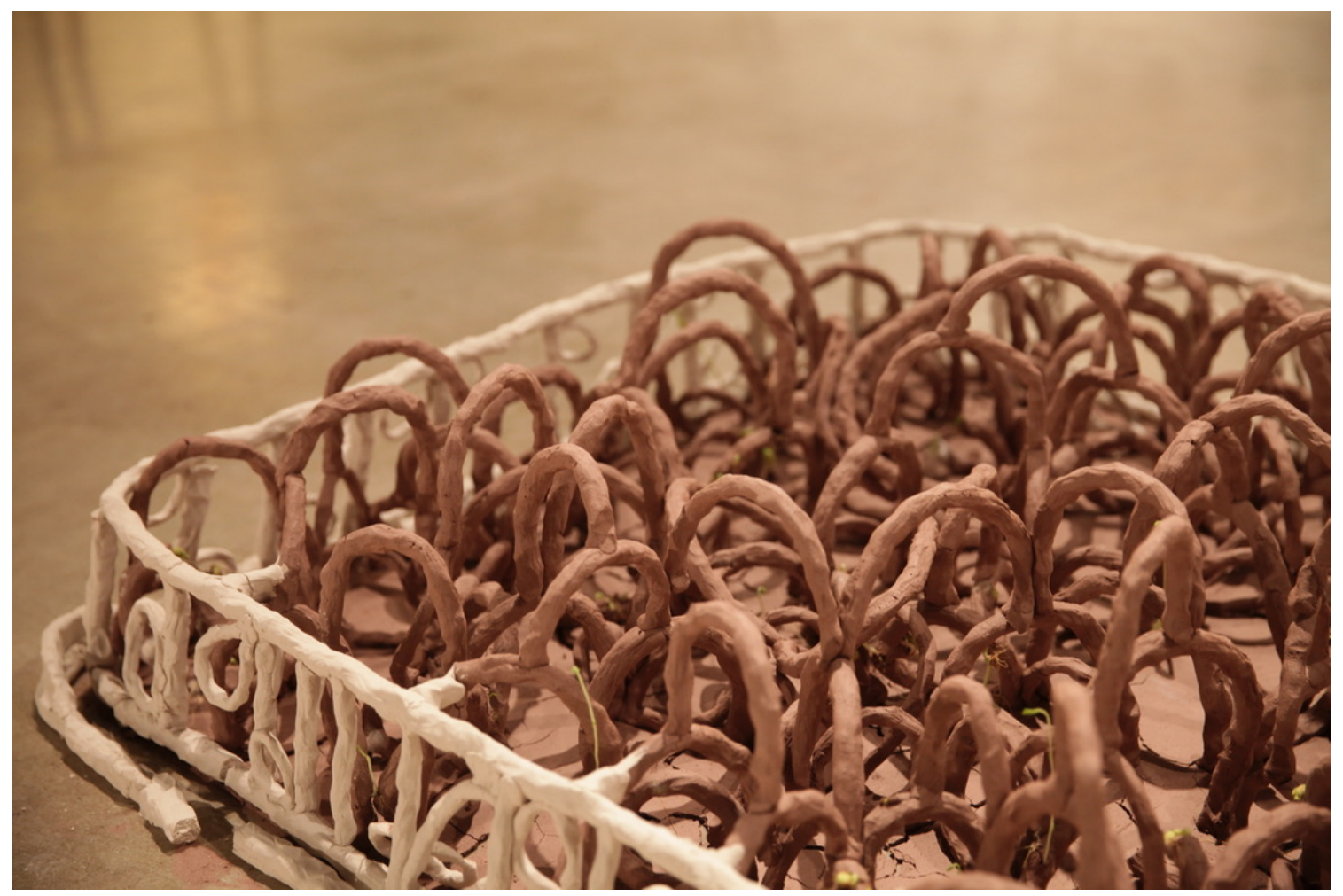

A-6. Bed (Corner Detail) 


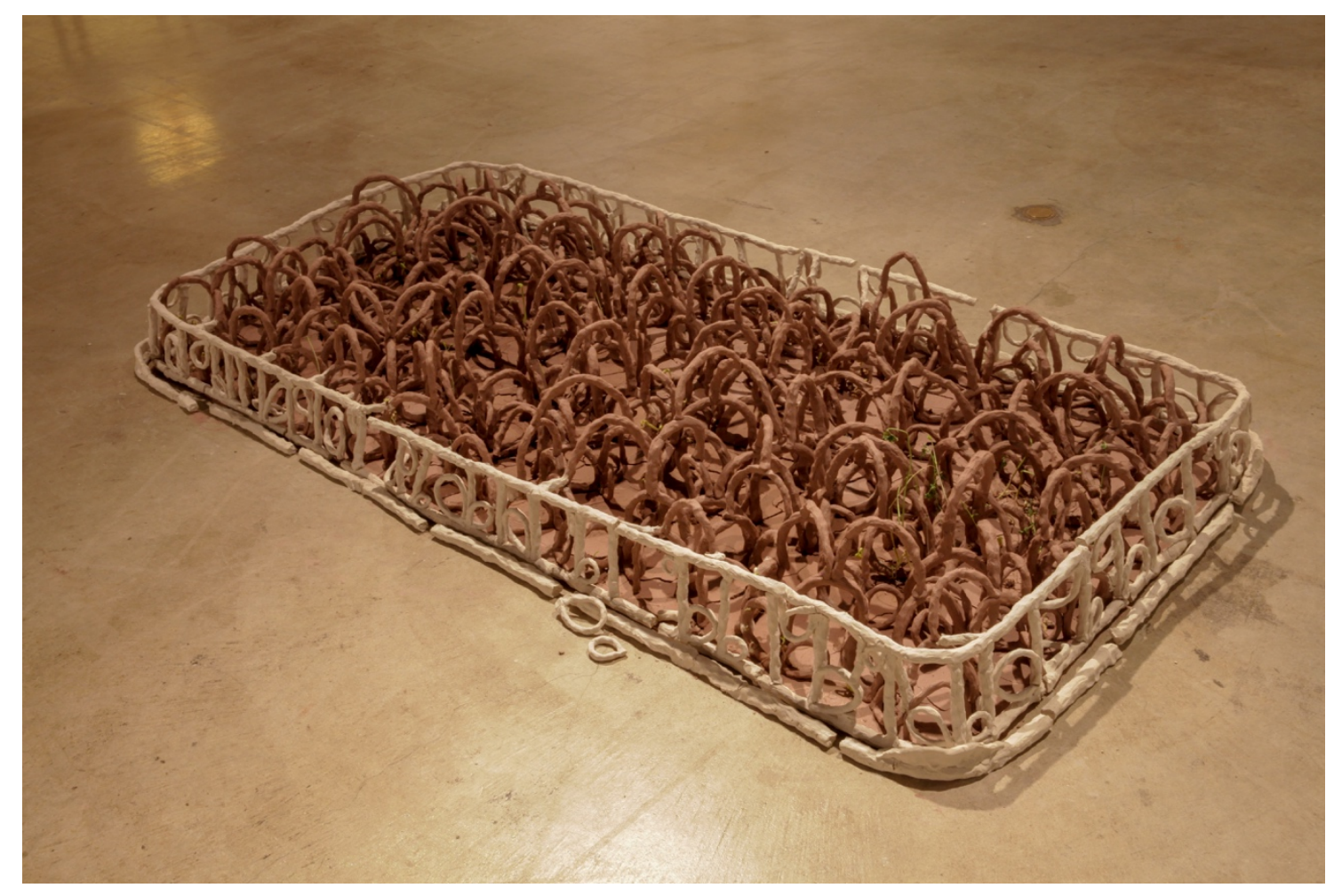

A-7. Bed (Full View)

$$
\begin{array}{r}
\text { Fragmentations } \\
\text { of a Flaziy Mind } \\
\text { kirsten } \\
\text { heteji }
\end{array}
$$

A-8. Show Title 


\section{APPENDIX B: LIST OF ARTWORKS}

1. Bed

Unfired Earthenware and Porcelain, Bean Sprouts

8.5” x 38” x 75” 2019

2. Chair

Earthenware and Porcelain (fired and unfired), Epoxy

$27.5 ”$ x 18” x 17”

2019

3. Window

Porcelain paper clay, Acrylic, LED lights,

$22 ”$ x 29” x 2”

2019

4. Curtain

Found curtain, Fired porcelain, Slip

$70 ”$ x 33” x 3”

2019

5. Table

Earthenware, Porcelain, Epoxy

$24.5 ”$ x 25” x 13.5”

2019

6. Lamp

Earthenware, Porcelain, Lamp hardware, Epoxy, Acrylic Paint

$28 ” \times 15.5 ”$ x 15.5”

2018

7. Show Title

Fired porcelain slip, Nails, Hot glue

$20 ”$ x $26 ”$ x $1.5 ”$

2019 